\title{
IMPACT ASSESSMENT OF CRUDE OIL WELL ON MANIHOT ESCULENTA (CRANTZ) AND QUALITY OF SURROUNDING SURFACE WATER BODIES
}

\author{
ANTHONY.B. OJEKALE ${ }^{1}$, PATRICK AKAS. ${ }^{2}$, CHIONYEDUA. T. ONWORDI ${ }^{3}$ and MALIK.O.LASISI ${ }^{\star 1}$
}

\author{
${ }^{1}$ Department of Biochemistry, Lagos State \\ University, Ojo, Lagos, Nigeria. \\ ${ }^{2}$ Centre for Environment, Science and \\ Sustainable Development, Lagos State \\ University, Ojo, Lagos, Nigeria. \\ ${ }^{3}$ Department of Chemistry, Lagos State \\ University, Ojo, Lagos, Nigeria.
}

\section{Correspondence}

Malik.O.Lasisi,

Department of Biochemistry,

Faculty of Science, Lagos State University, Nigeria.

Email.maliiklasisi@gmail.com

\begin{abstract}
:
Background:Exploration/exploitation of crude oil has impacted positively on the Nigerian economy and negatively on its environment This study assessed the impact presence of an oil well has on Manihot esculenta and quality of surface water in Aguleri, South Eastern Nigeria.

Materials and Methods:Cassava and water samples were collected from areas close to the crude oil well. Water samples were analysed for physicochemical properties viz; $\mathrm{pH}$, conductivity, temperature, turbidity total suspended solids using standard methods. Concentration ofmetals in the samples were determined using Atomic absorption spectrophotometer.

Results: Cassava proximate; moisture content (5.25), carbohydrate $(71.38 \%)$, crudeprotein $(9.10 \%)$, crude fibre $(5.20 \%)$, ash content $(4.01 \%)$ and crude fat $(1.56 \%)$. Concentration of metals analysed in Manihot esculenta; Copper $(13.8 \mathrm{mg} / \mathrm{kg})$, Nickel $(3.2 \mathrm{mg} / \mathrm{kg})$,Cadmium $(0.2 \mathrm{mg} / \mathrm{kg})$, Iron $(158.5 \mathrm{mg} / \mathrm{kg})$, Manganese $(7.0 \mathrm{mg} / \mathrm{kg})$, Chromium $(6.1 \mathrm{mg} / \mathrm{kg})$,Cobalt $(2.5 \mathrm{mg} / \mathrm{kg}$ )andLead $(1.8 \mathrm{mg} / \mathrm{kg})$. The concentrations of parametersanalyzed in water samples; $\mathrm{pH}$ (7.05), conductivity, $(62.30 \mu \mathrm{s} / \mathrm{cm})$, turbidity $(3.3 \mathrm{NTU})$, total dissolved solids (31.50 mg/l), totalsuspended solids, $(100 \mathrm{mg} / \mathrm{l})$ and nitrate $(0.5 \mathrm{mg} / \mathrm{l})$. Manganese and cobalt concentrations in water samples were withinallowable limits, while Iron, chromium, nickel and lead (two sampling points) were not. Ashvaluesofcassavaanalyzedwas high.

Conclusion:Water and cassava sampled have high concentrations of heavy metals, probably due contamination from crude oil exploration and/or oil spillage. Study recommends portable water for communities close to oil well for domestic use/irrigation. Furthermore, farming activities should be in areas far removed $(>19.4 \mathrm{~km})$ from the oil well to mitigate contamination of surface waters and farm produce.

Keywords:Oil well, water, Manihot esculenta, proximate analysis, potential toxic metals.
\end{abstract}




\section{INTRODUCTION}

Manihot esculenta (cassava) is the third most important source of calories in the tropics, after rice and maize. and sixth most important food crop after sugar cane, maize, rice, wheat and potato[1]. Cassava is an important food crop in the tropics and is cultivated everywhere in West Africa [2]. It is a major staple food in the developing world, grown primarily for it tuberous roots and providing a basic diet for over half a billion people [2]. It is one of the most popular drought-tolerant food crops [3] capable of growing on marginal soil. In terms of agriculture, Cassava has played and still continues to play a remarkable role in the agricultural development in Nigeria. It has been transformed from a minor crop recently into a cash crop $[4,5]$. It is one of the dominant carbohydrate rich staple crops grown in most countries in continental Africa, especially in Nigeria [6]. Though Nigeria is the highest producer of cassava in the world, she is also the world's largest consumer, leaving nearly nothing for export. Cassava is consumed in various forms, and by more than $80 \%$ of Nigeria's populace. Cassava is cultivated mostly in the southern parts of Nigeria.

Oil spill is the release of liquid petroleum hydrocarbon into the environment, especially marine areas due to human activity, and is a form of pollution [7]. Shell British Petroleum (now Royal Dutch Shell) discovered crude oil at Oloibiri, a village in the Niger Delta, and coproduction began in 1958 [8]. Presently, there are about 606 oil fields in the Niger Delta, of which 360 are on-shore and 246 off shore. Nigeria is presently the largest oil producer in Africa, and the sixth largest in the world, averaging about 2.7 million barrels per day as at 2006. The exploration of oil sometimes results in oil spillages, which poses serious threat to water and land environment. Spilled oil can harm the environment in several ways, including physical damages that have the direct impact to the habitat, and the toxicity of the oil itself, which can poison exposed organisms [9], with both short and long-term effects on all parts of the marine food web. Short-term effects vary with the type of environment, amount of oil, effect of waves and weather, and type of oil: light i.e., medium or heavy. Long-term effects may result to damage in the breeding of organisms, and also the migration of habitats thereby affecting future generations of marine life

Oil spills occurring in freshwater bodies are less publicized than spills into the ocean, even though freshwater oil spills are more frequent and often more destructive to the environment [10]. Freshwater bodies are highly sensitive to oil spills and are important to human health and the environment. These water bodies are often used for drinking water, and frequently serve as food sources for various freshwater organisms. All types of aquatic life, including freshwater organisms are susceptible to the deadly effects of spilled oil, including mammals, aquatic birds, fish, insects and vegetation [10].The effect of oil resource extraction on the environment of their communities has been very glaring in terms of its negative effect on the region [11]. Oil exploration and exploitation have over the last decade impacted disastrously on the physical environment, where oil-bearing communities, massively threatening their subsistent economy and the environment, and hence the entire livelihood and basic survival of the people. There is no doubt that the Nigerian oil industry has impacted on the country in a variety of ways. However, on the negative side, petroleum exploration and production also have adverse effects on farming, being the traditional means of livelihood of a large majority of the people of the oil producing communities. This study was conducted to examine the effects of the presence of an oil well on Manihot esculenta and the quality of surface water around it.

\section{MATERIALS AND METHODS}

\section{Study area}

The study was conducted around Aguleri oil well in Anambra State, Nigeria, about 31.2 kilometers from the capital city of Awka, Anambra State, South Eastern Nigeria. It lies between latitude $6^{0}$ $40^{1} 0.193^{11}$ North and Longitude $6^{0} 51^{1} 26.19^{11}$ East (Figure 1).

\section{Sample Site}

Samples of water and cassava tubers were collected from different locations around Aguleri Oil well, Anambra State Metropolis all within a $20 \mathrm{~km}$ radius. Coordinates were determined at the predetermined points of collection of both water and cassava samples.

\section{Determination of $\mathrm{pH}$, conductivity, temperature and turbidity}

A Horiba U-10 multimeter (Colorado, USA) was used to determine the $\mathrm{pH}$, temperature, conductivity and turbidity of the water [12].

\section{Total suspended solids}

Total suspended solids were determined by gravimetric method. Briefly, a clean dish was dried at $102-105^{\circ} \mathrm{C}$ in an oven to a constant weight. Thoroughly mixed sample $(25-100 \mathrm{ml})$ was accurately pipetted into a dish, weighed and evaporated to dryness on a steam bath. The residue was dried in an oven at about 103$105^{\circ} \mathrm{C}$ for 2 hours and reweighed. After cooling, the weight of the dish plus residue was constant within $0.5 \mathrm{mg}$. The weight of the dish was subtracted to obtain the weight of the total suspended solids [13]. 


\section{Water digestion}

Conical flasks were thoroughly washed and rinsed with distilled deionised water. $100 \mathrm{ml}$ of water sample was measured into conical flask. Twenty (20) ml concentrated nitric acid $\left(\mathrm{HNO}_{3}\right)$ was added into the $100 \mathrm{ml}$ of water and heated on hot plate at about $105^{\circ} \mathrm{C}$ until the solution reduced to about $50 \mathrm{ml}$, thereafter, $30 \mathrm{ml}$ of distilled deionised water was added. The solution was returned to the hot plate with the same temperature until the solution volume was $40 \mathrm{ml}$ to $50 \mathrm{ml}$. The solution was allowed to cool and filtered into a $100 \mathrm{ml}$ volumetric flask. Distilled deionised water was added to make up the volume to $100 \mathrm{ml}$. Heavy metal concentration was determined using a Unicam 939 (UK) Atomic absorption spectrophotometer [14]

\section{Cassava tuber digestion and potential toxic metals determination}

About $2 \mathrm{~g}$ of crushed cassava sample was added to a $30 \mathrm{ml}$ crucible. The sample was dissolved in $10 \mathrm{ml}$ of conc. $\mathrm{HNO}_{3}$. Sample was heated at $60^{\circ} \mathrm{C}$ for 30 minutes on a hot plate, and then allowed to cool. Afterwards, $3 \mathrm{ml}$ of $\mathrm{H}_{2} \mathrm{O}_{2}(30 \%)$ was added to the sample. Digestion was continued at $120^{\circ} \mathrm{C}$ for $1 \mathrm{hr}$. After cooling, the sample was diluted with deionized water and filtered. The filtrate was diluted to a total volume of $100 \mathrm{ml}$. The filtrates were refrigerated at $4^{\circ} \mathrm{C}$ prior to analysis. The same procedure was repeated for other samples. Heavy metal concentration was determined on a Unicam 939 Atomic Absorption Spectrophotometer [15]. All determinations were in triplicates.

\section{Proximate analysis}

Moisture, ash, crude fibre, fat, protein contents of the cassava samples were analysed[16]

\section{Mineral Analysis}

Two (2) $g$ of cassava tuber was placed in a crucible and burnt to ash in a muffle furnace at $550^{\circ} \mathrm{C}$ for 5 hours. This was subsequently transferred into the desiccator to cool. The ashed sample was further processed by dissolving with $1 \mathrm{ml}$ nitric acid and $1 \mathrm{ml} \mathrm{HCl}$, and the volume made up to $100 \mathrm{ml}$. The resulting mix was analysed for $\mathrm{Na}, \mathrm{Ca}, \mathrm{K}, \mathrm{Mg}, \mathrm{Cu}$, and $\mathrm{Zn}$ using atomic absorption spectrometry [16]

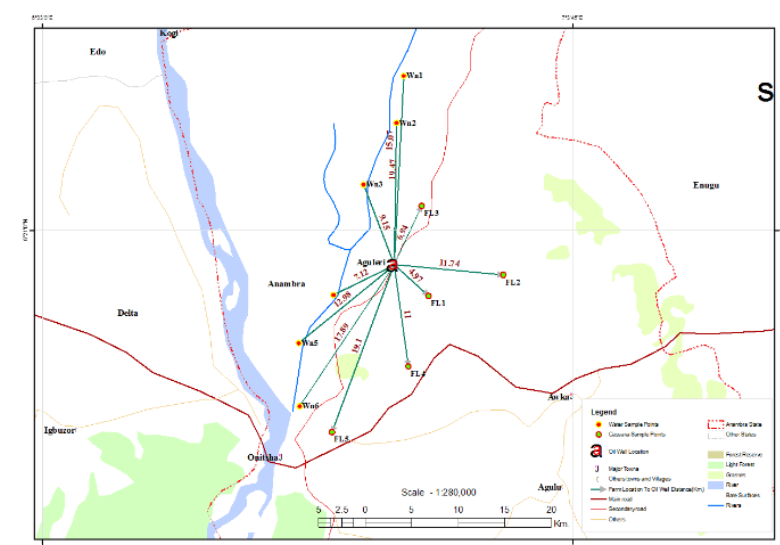

Figure 1: Map (drawn to scale) showing samples (cassava and water) collection points and their coordinates.

\section{RESULTS AND DISCUSSION}

Table 1: Physicochemical analysis data of surface water samples

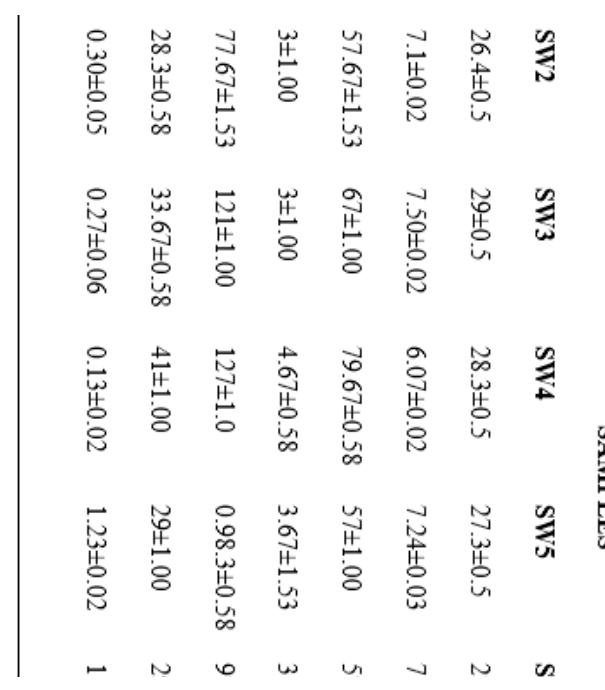

SW - Surface water.

WHO - World Health Organization.

ND - not detected (Detection limit: Cobalt

$=0.01$, Lead $=0.01$, Cadmium $=0.01$ ).

SON - StandardOrganization of Nigeria

Table 2. Analysis for potential toxic metals in surface water 
Table3. Analysis for toxic heavy metal and minerals in cassava samples

FL - Farm (farm location)

WHO - World Health Organization

FAO - Food and Agriculture Organization

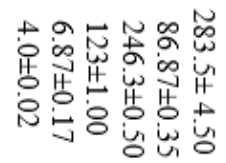

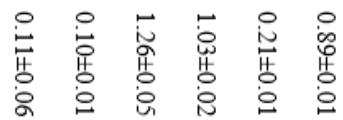

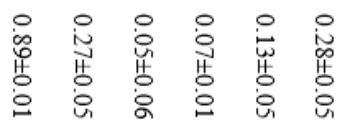

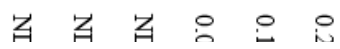

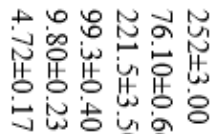

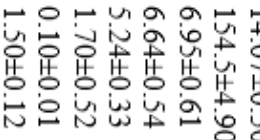

은

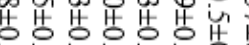

总吉心志过总

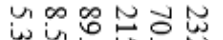

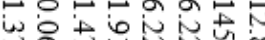

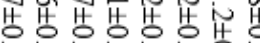

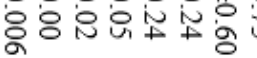

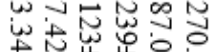

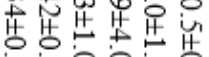

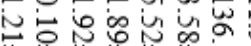

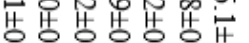

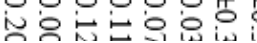

Table 4. Proximate analysis for Manihot esculenta (cassava) tuber

\begin{tabular}{lllllll}
\hline PARAMETERS & \multicolumn{7}{c}{ FLl } & \multicolumn{1}{c}{ FL2 } & FL3 & FL4 & \multicolumn{1}{c}{ FL5 } & mean \pm sd \\
& \multicolumn{1}{c}{ sL } \\
Moisture content (\%) & $5.57 \pm 0.73$ & $5.57 \pm 0.25$ & $5.03 \pm 0.66$ & $4.59 \pm 0.63$ & $5.24 \pm 0.73$ & $5.25 \pm 0.20$ \\
Ash content (\%) & $3.50 \pm 0.18$ & $4.06 \pm 0.07$ & $4.61 \pm 0.36$ & $4.26 \pm 0.23$ & $3.60 \pm 0.18$ & $4.01 \pm 0.21$ \\
Crude protein (\%) & $9.94 \pm 0.38$ & $10.27 \pm 0.15$ & $7.79 \pm 0.21$ & $7.08 \pm 0.03$ & $10.40 \pm 0.43$ & $9.10 \pm 0.24$ \\
Crude fibre (\%) & $6.67 \pm 2.06$ & $4.10 \pm 0.02$ & $5.81 \pm 0.17$ & $4.69 \pm 0.51$ & $4.70 \pm 0.26$ & $5.20 \pm 0.61$ \\
Crude fat (\%) & $1.45 \pm 0.11$ & $1.67 \pm 0.11$ & $1.51 \pm 0.04$ & $1.52 \pm 0.07$ & $1.62 \pm 0.25$ & $1.56 \pm 0.12$ \\
Carbohydrate (\%) & $72.67 \pm 0.76$ & $74.9 \pm 0.62$ & $67.17 \pm 0.65$ & $70.95 \pm 0.37$ & $71.2 \pm 1.21$ & $71.38 \pm 0$ \\
& & & & & & \\
\hline
\end{tabular}

FL - Farm (farm location) 
Water is essential to life and the health of the environment, and its usefulness is dependent on its quality and nontoxic nature. Anything that affects the quality of water affects the equilibrium of all that depend on the water body for one thing or the other. The presence of an oil well in a water environment causes a major impact on the riverine ecosystem and may likely be a determinant for poor water quality in oil producing communities. Physicochemical analysis data of water samples showed that all samples fall within the allowable limit for the parameters investigated, except that of the temperature (table 1). The water temperature has no direct health impact; however, this may affect the aquatic lives if it exceeds the tolerable level, following which the aquatics would be uncomfortable.

Values for parameters like $\mathrm{pH}$, conductivity, turbidity, total dissolved solids, total suspended solids and nitrate falls within the permissible limits set by WHO/SON standards. The overall $\mathrm{pH}$ range of natural water is generally between 6.5 and 8.5 . The average value of $\mathrm{pH}$ in the water samples is $7.05 \mathrm{mg} / \mathrm{l}$ which is within allowable limit of WHO and Standard Organisation of Nigeria in water, and will encourage growth and proliferation of aquatic animals. Turbidity in water refers to the reduction of transparency due to the presence of particulate matter such as clay or silt, finely divided organic matter, plankton or other microscopic organisms. The average detected value of turbidity in the water samples is 3.3NTU which is within allowable limit of WHO and Standard Organisation of Nigeria in water. Turbidity level ensures the aquatic animals are not under any form of oxidative stress with the organism's antioxidant systems working well [17]. Suspended solids indicate water turbidity. Suspended solids cause the water to be milky or muddy looking due to the light scattering from the very small particles in water (WHO, 1997). The maximum allowable TSS limit set by $\mathrm{WHO}$ and Standard Organisation of Nigeria is $500 \mathrm{mg} / \mathrm{l}$. The average TSS values analyzed falls within the allowable limit set by $\mathrm{WHO}$ and Standard Organisation of Nigeria standard. Total dissolved solids is the term used to describe the inorganic salts and small amount organic matter present in solution in water (WHO, 1996). The average value TDS in water samples is $31.50 \mathrm{mg} / \mathrm{l}$ which fall within allowable limit of WHO and Standard Organisation of Nigeria. Nitrate in water is either due to oxidation of ammonium compounds or due to reduction of nitrate [18]. It can be toxic to certain aquatic organisms even at concentration of $1 \mathrm{mg} / \mathrm{l}$. In excessive limits, it contributes to the illness known as methemoglobinemia in infants. The average value of nitrate in water samples is $0.5 \mathrm{mg} / \mathrm{l}$ which fall within allowable limit of $\mathrm{WHO}$ and Standard Organisation of Nigeria.

The results of the heavy metal analysis in the water samples (SW1 to SW6) analysed is shown in table 2 . The result showed that some of the metals (iron $(0.9 \mathrm{mg} / \mathrm{l})$, chromium $(0.4 \mathrm{mg} / \mathrm{l})$, nickel $(0.3 \mathrm{mg} / \mathrm{l})$, vanadium $(0.3 \mathrm{mg} / \mathrm{l})$ and lead $(0.1 \mathrm{mg} / \mathrm{l}))$ exceeded the permissible limit set by $\mathrm{WHO}$ and Standard Organization of Nigeria in water. High concentration of some metals in water has been reported to accumulate in different parts of various fish species [19]. The Iron in water has been reported to cause joint pain, liver disease and heart failure in men. High concentration of chromium can is known to cause various systemic disorders [20], high concentrations of is associated with multi-organ dysfunction [21], while high concentrations of lead can lead to kidney disease, damage of nervous system and circulatory system. High concentration of vanadium can damage to the lungs, throat and nose and can also result in coughing which can last for number days on exposure. A cumulation of the high concentration of all these metals may be dangerous/fatal to animals within the environment. The concentrations of metals like copper $(1.0 \mathrm{mg} / \mathrm{l})$, manganese $(0.3 \mathrm{mg} / \mathrm{l})$, cobalt $(0.2 \mathrm{mg} / \mathrm{l})$ and cadmium $(0.05 \mathrm{mg} / \mathrm{l})$ fall within allowable limits of $\mathrm{WHO}$ and Standard Organisation of Nigeria.

Cassava is a predominant food crop cultivated in Anambra State. However, the presence of contamination may affect the overall qualities of the vital nutrients. Table 3 showed the result obtained from the heavy metal analysis in cassava. The result revealed that all cassava samples analysed had concentrations of the potential toxic metals (iron, manganese, vanadium, chromium, cobalt and lead) exceeding the maximum allowable limit by WHO standard, while the concentration of copper, nickel, and cadmium fall within the allowable limit WHO standard in food.

Proximate analysis of cassava samples (FL1 to FL5) is presented in table 4. Manihot esculenta tubers contain carbohydrate, protein, crude fat and crude fibre. The carbohydrate content in all the samples analysed was high with the average concentration of $71.38 \%$. However, this is above the percentage content of between 32 $35 \%$ concentration by IITA standards as well as $32-35 \%$ stated way back by Oluwole 
(2004). Also, protein and crude fibres were high with the concentration values of $9.1 \%$ and $5.2 \%$ against the IITA standards of $0.95-6.42 \%$ and $1.11 \%$ as well as stated values of $2-3 \%$ and $1 \%$ for protein and crude fibre respectively [22]. The crude fat is low in concentration with the value of $1.6 \%$ as compared to IITA standard of $3.5 \%$ for cassava, however, this value is high as compared to $0.1 \%$ value stated [22]. The average moisture content for all the samples was found to be $52.54 \%$. This is averagely low as compared to the IITA standard of $70.24 \%$ moisture content for cassava. This is an indication that the cassava sample may have longer shelf life. High moisture content encourages the growth of micro-organisms which usually leads to spoilage. The average ash values for all the samples were high as compared to the IITA standard of $0.5 \%$ and the stated values of between $0.75-2.5 \%$ for cassava [22]. This is suggestive of high metal content. The result revealed high mineral contents of average values of $81 \mathrm{mg} / \mathrm{kg}, 233 \mathrm{mg} / \mathrm{kg}, 111 \mathrm{mg} / \mathrm{kg}$, $8.1 \mathrm{mg} / \mathrm{kg}$ and $4.2 \mathrm{mg} / \mathrm{kg}$ for sodium, magnesium, calcium, zinc and copper respectively. These values are relatively high as compared to FAO standard. However, the average potassium concentration in all the samples is $261.7 \mathrm{mg} / \mathrm{kg}$ which fall within allowable limit of the standard by FAO. High concentration of these minerals poses great danger to consumers of this food crop. Oil pollution and other forms of environmental stress are known to induce oxidative stress in plants via the generation of reactive oxygen species with the attendant consequence of attacking and damaging of bio-molecules including proteins, lipids and nucleic acids [23]. There are reports[24, 25] documenting the effect of oil spillage on the environment and peoples[26], particularly the Niger-Delta region of Nigeria.

Conclusively, crude oil exploration activities when not properly regulated and monitored impacts negatively on the environment inclusive of farm produce and water bodies.

\section{COMPETING INTERESTS}

Authors have declared that no competing interests exist.

\section{AUTHORS' CONTRIBUTIONS}

ABO designed the study and wrote the first draft of the manuscript. PA conducted the experiment and processed the data. CTO and
MOL processed the data and edited the manuscript.

\section{REFERENCES}

1. Otekunrin, O.A. and Sawicka, B., Cassava, a 21st century staple crop: how can Nigeria harness its enormous trade potentials. Acta Scientific Agriculture, 2019. 3(8), p.194-202.

2. Oshunsanya, S. and Nwosu, N., Soilwater-crop relationship: a case study of cassava in the tropics. Cassava, 2018. (p.163).

3. Zhu, Y., Luo, X., Nawaz, G., Yin, J. and Yang, J., Physiological and biochemical responses of four cassava cultivars to drought stress. Scientific reports, 2020. 10(1), p.1-12.

4. Parmar, A., Sturm, B. and Hensel, O., Crops that feed the world: Production and improvement of cassava for food, feed, and industrial uses. Food Security, 2017. 9(5), p.907-927.

5. Olarinde, L.O., Abass, A.B., Abdoulaye, T., Adepoju, A.A., Adio, M.O., Fanifosi, E.G. and Wasiu, A., The influence of social networking on food security status of cassava farming households in Nigeria. Sustainability, 2020. 12(13), p.5420.

6. Nzekwe, L.S.O. and Afolami, C., Technology Adoption of Improved Practices by Small Scale Cassava Farmers in Agriculture Development Programme $(A D P)$ Zones of Ogun State. In Proceeding of the 35th Annual Conference of the Agricultural Society of Nigeria, held at the University of Agriculture, Abeokuta, Nigeria, 2001. (p. 331).

7. Etkin, D.S., Analysis of oil spill trends in the United States and worldwide. In International oil spill conference. American Petroleum Institute, 2001. 2001(2), p.1291-1300.

8. Watts, M. ed., Curse of the black gold: 50 years of oil in the Niger Delta.Power House Books, 2008.

9. Nnaemeka, A.N., Environmental pollution and associated health hazards to host communities (Case study: Niger delta region of Nigeria). Central Asian Journal of Environmental Science and Technology Innovation, 2020. 1(1), p.30-42.

10. Nomack, M. and Cleveland, C., Environmental impacts of oil spills. 
Encyclopedia of Earth. Eds. Cutler J. Cleveland (Washington, DC: Environmental Information Coalition, National Council for Science and the Environment), 2010.

11. Pitkin, J., Oil, oil, everywhere: Environmental and human impacts of oil extraction in the Niger Delta. 2013.

12. Davies, O.A., Seasonal Variation of The Physico-Chemistry Quality of a Tributary of The Bonny Estuary, Rivers State, Nigeria. Journal of Advances in Biology, 2013. 2(1).

13. Ademoroti, C.M.A., Standard methods for water and effluent analysis 1st edition. 1996.

14. Adeniyi, A.A., Yusuf, K.A. and Okedeyi, O.O., Assessment of the exposure of two fish species to metals pollution in the Ogun river catchments, Ketu, Lagos, Nigeria. Environmental Monitoring and Assessment, 2008. 137(1), p.451-458.

15. Zheljazkov, V.D. and Warman, P.R., Comparison of three digestion methods for the recovery of 17 plant essential nutrients and trace elements from six composts. Compost science \& utilization, 2002. 10(3), p.197-203.

16. Official, A.O.A.C., Methods of analysis of AOAC International. AOAC International, Maryland, USA (2003), 2005.

17. Suzuki, J., Imamura, M., Nakano, D., Yamamoto, R. and Fujita, M., Effects of water turbidity and different temperatures on oxidative stress in caddisfly (Stenopsyche marmorata) larvae. Science of the total environment, 2018. 630, p.1078-1085.

18. Ward, M.H., Jones, R.R., Brender, J.D., De Kok, T.M., Weyer, P.J., Nolan, B.T., Villanueva, C.M. and Van Breda, S.G., Drinking water nitrate and human health: an updated review. International journal of environmental research and public health, 2018. 15(7), p.1557.
19. Canli, M. and Atli, G., The relationships between heavy metal ( $\mathrm{Cd}, \mathrm{Cr}, \mathrm{Cu}, \mathrm{Fe}, \mathrm{Pb}, \mathrm{Zn}$ ) levels and the size of six Mediterranean fish species. Environmental pollution, 2003. 121(1), p.129-136.

20. World Health Organization, Chromium in Drinking-water (No. WHO/HEP/ECH/WSH/2020.3). World Health Organization, 2020.

21. Genchi, G., Carocci, A., Lauria, G., Sinicropi, M.S. and Catalano, A., Nickel: Human health and environmental toxicology. International journal of environmental research and public health, 2020. 17(3), p.679.

22. Oluwole, O.B., Olatunji, O.O. and Odunfa, S.A., A process technology for conversion of dried cassava chips into "Gari". Nigerian Food Journal, 2004. 22(1), p.65-77.

23. Odjegba, V.J. and Badejo, J.O., Crude oil induce oxidative stress in Capsicum annum. Nature and Science, 2013. 11(2), p.46-50.

24. Harrison, U.E., Osu, S.R. and Ekanem, J.O., Heavy metals accumulation in leaves and tubers of cassava (Manihot esculenta Crantz) grown in crude oil contaminated soil at Ikot Ada Udo, Nigeria. Journal of Applied Sciences and Environmental Management, 2018. 22(6), p.845-851.

25. Chinonyerem, N.T., Ntor-Ue, M., Chukwudi, I.C. and Chinedum, O., Economic implications of marine oil spill to Nigeria: $A$ case for improvement in coastal pipeline management and surveillance practices. International Journal of Economy, Energy and Environment, 2017. 2(3), p.40.

26. Bruederle, A. and Hodler, R., Effect of oil spills on infant mortality in Nigeria. Proceedings of the National Academy of Sciences, 2019. 116(12), p.54675471. 